\title{
EIF2S1 Gene
}

National Cancer Institute

\section{Source}

National Cancer Institute. EIF2S1 Gene. NCI Thesaurus. Code C104187.

This gene plays a role in translation initiation. 